\title{
SOCIAL CAPITAL AMONG URBAN AGRICULTURE PROGRAM PARTICIPANTS IN KLANG PERDANA SELANGOR, MALAYSIA
}

\author{
Nur Shuhamin Nazuri ${ }^{1}$ \\ Department of Social and Development Science, Faculty of Human Ecology, University Putra Malaysia. \\ (Email: nurshuhamin@gmail.com) \\ Nobaya Ahmad ${ }^{2}$ \\ Department of Social and Development Science, Faculty of Human Ecology, University Putra Malaysia.
}

Received date: 11-09-2019

Revised date: 07-10-2019

Accepted date: 04-12-2019

Published date: 12-12-2019

To cite this document: Nazuri, N. S., \& Ahmad, N. (2019). Social Capital among Urban Agriculture Program Participants in Klang Perdana Selangor, Malaysia. International Journal of Modern Trends in Social Sciences, 2(10), 47-56.

DOI: $10.35631 / \mathrm{IJMTSS} .210005$

\begin{abstract}
The aim of the study is to measure the level of social capital among urban agriculture program participants in Klang Perdana, Selangor. The study employed quantitative research using a survey method. A total of 30 respondents were involved to answer the questionnaire in the preliminary study. The findings were based on the pilot test prior to the commencement of the actual data collection. The result indicated that the community in Klang Perdana who participated in the urban agriculture program have a high level of social. Analysis using t-test and ANOVA revealed that age and gender variables have a significant effect on their social capital. Social capital was found to be important in increasing the participation of the community in urban agriculture programs.
\end{abstract}

Keywords: Social Capital, Urban Agriculture Program, Klang Perdana Community

\section{Introduction}

Urban agriculture is defined as agriculture activities in a vacant lot, balconies, gardens and containers existing around the urban areas for their own consumption or profit making (FAO, 1999). The important part of urban agriculture is giving impact on livelihood strategies in a food security as a whole and providing an extra income source, enhance dietary needed or helping to protect inability access in the food supply (Ruel et al. 1998; Vall, Selod and Shalizi 2006). Urban agriculture may contribute to food security in many ways. Food security occurs when all people at any times have physical and economic access to enough, safe and nutritious food to meet their nutrition requirement and food preferences for an active and healthy life via all the sources (FAO, 1999). Once a household practise urban agriculture, they are able to 
produce their own food, easy to access on nutritional rich food which will increase the quality of diet. Hence, urban agriculture provides more stable food sources to the community; enhance the quantity and quality of perishable foods in urban areas (Poulsen et al., 2015). According to Muhlke (2010), urban agriculture is becoming an important element among communities across the country. All the vacant lots provide a space for communities to grow their own food for their purposes and engage for local food system to increase their food security and also their engagement with the community. Freeman (1991) on his early study in urban agriculture in Nairobi found that the upper or middle class categories of people are frequently active to join the urban agriculture activities. Their intention of participating on the program is for consumption itself rather than as a business venture. Instead of livelihood framework, the urban agriculture encompasses an interaction towards social capital as they contribute to food security. Social capital is described as an ability or skill to interact with each other among the group members. Social capital comprises the features of social organization including social trust, norms and network that can improve the efficiency in the community (Putnam, 2000). For the urban agriculture perspective, social capital act as element that help the community to share their knowledge, skills and experience to work for the benefit of the community (Kilpatrick, 2002). Midgley and Livermore (1998) in their study has suggested that higher level of social capital is related to improve the development of the communities. Other than that, by practicing urban agriculture together among the community, they are able to strengthen their relationship with each other in a same way helping them to build up their social capital.

\section{Literature Review}

Social capital in this study encompasses three main elements which are bonding, bridging and linkage. The concepts of bonding, bridging and linking social capital has recognized as useful characteristics in multiple dimensions of social capital among community level (Gittell and Vidal, 1998; Putnam, 2001; Grant, 2001; Levitte, 2003; Wakefield and Blake, 2005). Bonding social capital define as a strong, dense ties between people to know each other well, such as family members, close friends, neighbours and members of the group (Woolcock and Narayan, 2000; Gittell and Vidal, 1998; Wakefield and Blake, 2005; World Bank, 2000). Bonding concept could associate individual who has a similar socio-demographic characteristics and has high degree of homogeneity (Grootaert et al., 2004; Field, 2003; World Bank 2000; Putnam, 2001). Community in the same bonding social capital shows the same interest, goal, sociofinancial position and demographic characteristics which reinforce identities and enhance the level of homogeneity (Grootaert, C., et al., 2004; Field, J., 2003; World Bank, World 2000; Putnam, 2002, Gittell and Vidal, 1998). Putnam (2001) stated that bonding can be directed to the inside of the group and tend to strengthen the homogenous group. In this study context, the roles of bonding social capital was interaction, cooperation and close support from members of urban agriculture communities targeted to ensure the UA program run smoothly and sustainably

Meanwhile, the bridging social capital describes the relationship of different people in different group or social class. Bridging concept brings together group of people from a different class whilst the bonding ties the relationship among them who are similar (Putnam, 2001). This networks connecting external resources horizontally and fill the structural holes of the system obtain from the community. Diversity of social networks among community will enhance the bridging of social capital. Bridging concept is very crucial to the community development as it is a causal factor to determine well-being of different community. In this study, the bridging concept facilitates the process of "getting ahead" which includes various networks among communities and lend opportunities for community to obtain several benefits from the others. 
Linkage acts as a third category in social capital encompasses of relationship between group of members and authority people (Grootaert, et al., 2004; Gittell and Vidal, 1998). This form of social capital is valuable in terms of improved the access of resources from the authority such as financial and technical support, information receiving and etc (Grootaert, et al., 2004; Levitte, 2003; Woolcock, 2001; Narayan and Pritchett, 2000). Within the context of urban farming study, linking social capital closely related to the extension agriculture which is Department of Agriculture. Basically, the stakeholders will provides input such as seeds, fertilizers and tools as well as advisory services, workshops and seminar to educate and help clients in receiving knowledge and skills to cope with the problem facing in a field. In this study, all these three concepts (bonding, bridging and linkage) in social capital should bring together in order to enhance the positive impact in the urban agriculture community and develop sustainability in the program.

Generally, urban agriculture is a new idea in Malaysia. Urban agriculture in Malaysia is a tool for sustainability development that should be scrutinized further for food security purpose or related services. Having recognized the importance of urban agriculture, urban agriculture program has been introduced and obtain full of attention from government. This can be realized from the formation of urban agriculture division under the Department of Agriculture Malaysia in 2010 which initiate and promote the community to engage with agricultural activities in the city to reduce the cost of living. Other than that, the purpose of this program is to strengthen the relationship among the community members who are involved in the program. However, the questions that need to be raised in this study are to what extent does the urban agriculture program increases the social capital of the community and what kind of characteristics among respondents that will influence the social capital towards participation in urban agriculture. In this pilot study, we chose Klang Perdana community case study to find out more about the role of participation in urban agriculture and its influence on social capital.

Klang Perdana garden is located at Klang Valley area in Selangor. This urban agriculture community garden has been initiated by Dr Abdul Aziz Sahat, one of the community members and it was almost one and a half year of their involvement on that program. MARDI and the Agriculture Department were the important stakeholder who has played the important role to provide an exposure and information regarding on planting technology and method to the community. In addition, they are also received several support from both stakeholders such as agriculture equipment, plant materials and also financial aid. Hence, the purpose of the program is to strengthen the relationship among the community in the residents by providing a healthy lifestyle activity besides to have their own continuous basic supply of greens as well. This program will not only give them an opportunity to grow their own vegetables in their residential area, but it will give them to build a new relationship with their neighbour and hopefully this program could be sustainable and contribute to positive impact to the community.

\section{Material and Methods}

A quantitative approach was employed for this study. A total of 30 people from Klang Perdana community were selected as respondents. This study is a pilot test which is a small study to test data collection instruments and sample recruitment strategies. A structured questionnaire was used in this study and has been distribute to the selected respondents. The data was collected on $31^{\text {st }}$ July 2018 during the community gardening gathering. Self-administered method was employed in the data collection process. The instrument used to measure social capital was adopted from existing literature (Ibrahim, 2016) and modified to suit with the study area. Social capital instrument consisted of 3 domains which are bonding, bridging and linkage. Each of 
domains comprises of 6 items for bonding, 7 items for bridging and 5 items for linkage with 5 points likert scale ( $1=$ strongly disagree, $2=$ disagree, $3=$ neutral, $4=$ agree, $5=$ strongly agree). Data was analysed using SPSS version 23. To achieve the objective of the study, descriptive analysis such as frequency, percentage, mean and standard deviation were employed whereas inferential statistics such as t-test and ANOVA were used to reveal the significant between independent and dependent variable. The independent variables comprise of age, gender, marital status, level of education, working sector and household size whilst dependent variable is social capital.

\section{Results}

Let us explain on the socio-demography of the respondents in Klang Perdana in Table 1. Referring to the table, slightly half of the respondents $56.7 \%$ are male compared to female respondents which are $43.3 \%$. Thus, it concludes that most of participant on this program are from male group. Male respondents play a major part on this program since they have much more time to involve with all this community work. For the age categories, both of categories (41-50 years old) and (51-60 years old) has highest and similar percentage which are $33.3 \%$. Majority of the respondents came from older age ranged group as most of them have retired and could spend their leisure time to join the community program. Majority of the respondents (90\%) are married and from Secondary school/vocational school (80\%). Based on the study, it was recognized that more than half $(53.3 \%)$ of the respondents are not from government or private sector. Mostly of them are self-employed and have their own business. Last but not least, most of them (70\%) have number of family around (4-6 members) followed by 13 members (16.7) and $>7$ members (13.3).

Table 1: Socio-Demographic of Respondents $(n=30)$

\begin{tabular}{|c|c|c|c|c|}
\hline Variables & Frequency & $(\%)$ & Mean & SD \\
\hline $\begin{array}{l}\text { Gender } \\
\text { Male } \\
\text { Female } \\
\end{array}$ & $\begin{array}{l}17 \\
13 \\
\end{array}$ & $\begin{array}{l}56.7 \\
43.3 \\
\end{array}$ & & \\
\hline $\begin{array}{l}\text { Age } \\
31-40 \\
41-50 \\
51-60 \\
61 \text { and above }\end{array}$ & $\begin{array}{l}1 \\
10 \\
10 \\
9\end{array}$ & $\begin{array}{l}3.3 \\
33.3 \\
33.3 \\
30.0 \\
\end{array}$ & 54.10 & 7.86 \\
\hline $\begin{array}{l}\text { Marital status } \\
\text { Single } \\
\text { Married } \\
\text { Widow }\end{array}$ & $\begin{array}{l}1 \\
27 \\
2 \\
\end{array}$ & $\begin{array}{l}3.3 \\
90.0 \\
6.7 \\
\end{array}$ & & \\
\hline $\begin{array}{l}\text { Level of education } \\
\text { Primary school } \\
\text { Secondary } \\
\text { school/vocational } \\
\text { College/university }\end{array}$ & $\begin{array}{l}- \\
24 \\
6\end{array}$ & $\begin{array}{l}- \\
80.0 \\
20.0\end{array}$ & & \\
\hline $\begin{array}{l}\text { Working sector } \\
\text { Government } \\
\text { Private } \\
\text { Others }\end{array}$ & $\begin{array}{l}3 \\
11 \\
16 \\
\end{array}$ & $\begin{array}{l}10.0 \\
36.7 \\
53.3 \\
\end{array}$ & & \\
\hline $\begin{array}{l}\text { Household size } \\
1-3\end{array}$ & 5 & 16.7 & 4.77 & 1.59 \\
\hline
\end{tabular}




\begin{tabular}{|l|l|l|l|l|}
\hline $4-6$ & 21 & 70.0 & & \\
$>7$ & 4 & 13.3 & & \\
\hline
\end{tabular}

Subsequently, the social capital of respondents towards urban agriculture program is depicted in table 2. Based on the statement of "After participating in urban agriculture program, we do a lot of work together in a team." was recorded as the highest mean score in bonding domain which is 4.900 followed by "After participating in urban agriculture program, I'm always communicating with members who are involved in the program." as a second highest (4.833) and the third one is "After participating in urban agriculture program, I'm regularly provide help to my neighbour" and the statement "After participating in urban agriculture program, I'm always share the responsibility as well as common interest with my neighbour" with the value 4.8. For the bridging aspects, the highest mean score were recorded by the statement "I've learned a lot of farming method from other community after participating in urban agriculture program" $(\mathrm{M}=4.867)$ whilst the lowest mean score statement is "After participating in the urban agriculture program, members from the other community are willing to assist us" with the value 4.50. The linkage domain showed the highest mean score $(\mathrm{M}=4.667)$ with the statement "We and other urban agriculture community have organized a small discussion and consultation on farming activities matter" whilst the lowest mean score is $M=4.267$ with the statement "We've provided several services, help and support to other urban agriculture community".

Table 2: Social Capital on Urban Agriculture Program (N=30)

\begin{tabular}{|l|l|l|l|l|l|l|l|l|l|}
\hline STATEMENTS & $\mathbf{1}$ & $\mathbf{2}$ & $\mathbf{3}$ & $\mathbf{4}$ & $\mathbf{5}$ & \multicolumn{1}{|l|}{ SD } & Mean \\
\hline Bonding & & & & & \\
\hline $\begin{array}{l}\text { After participating in urban agriculture } \\
\text { program, we do a lot of work together in a } \\
\text { team. }\end{array}$ & 0.0 & 0.0 & 0.0 & 10.0 & 90.0 & 0.305 & 4.900 \\
\hline $\begin{array}{l}\text { After participating in urban agriculture } \\
\text { program, I'm always communicating with } \\
\text { members who are involved in the program. }\end{array}$ & 0.0 & 0.0 & 0.0 & 16.7 & 83.3 & 0.379 & 4.833 \\
\hline $\begin{array}{l}\text { After participating in urban agriculture } \\
\text { program, I'm regularly provide help to my } \\
\text { neighbor. }\end{array}$ & 0.0 & 0.0 & 0.0 & 20.0 & 80.0 & 0.407 & 4.800 \\
\hline $\begin{array}{l}\text { After participating in urban agriculture } \\
\text { program, I'm always share the } \\
\text { responsibility as well as common interest } \\
\text { with my neighbor. }\end{array}$ & 0.0 & 0.0 & 0.0 & 20.0 & 80.0 & 0.407 & 4.800 \\
\hline $\begin{array}{l}\text { I put the whole trust on my neighbor to } \\
\text { handle the project if I'm not around. }\end{array}$ & 0.0 & 0.0 & 0.0 & 10.0 & 90.0 & 0.430 & 4.767 \\
\hline $\begin{array}{l}\text { After participating in urban agriculture } \\
\text { program, my neighbors are willing to assist } \\
\text { me if I need a help }\end{array}$ & 0.0 & 0.0 & 0.0 & 23.3 & 76.7 & 0.430 & 4.767 \\
\hline Bridging & & & & & & & & & \\
\hline $\begin{array}{l}\text { I've learned a lot of farming method from } \\
\text { other community after participating in } \\
\text { urban agriculture program. }\end{array}$ & 0.0 & 0.0 & 0.0 & 13.3 & 86.7 & 0.346 & 4.867 \\
\hline
\end{tabular}




\begin{tabular}{|c|c|c|c|c|c|c|c|}
\hline $\begin{array}{l}\text { I'm always communicating with members } \\
\text { from other urban agriculture community } \\
\text { after participating in urban agriculture } \\
\text { program. }\end{array}$ & 0.0 & 0.0 & 3.3 & 10.0 & 86.7 & 0.461 & 4.833 \\
\hline $\begin{array}{l}\text { After participating in urban agriculture } \\
\text { program, we're always sharing our } \\
\text { responsibility and interest with other urban } \\
\text { agriculture community members. }\end{array}$ & 0.0 & 0.0 & 3.3 & 23.3 & 73.3 & 0.535 & 4.700 \\
\hline $\begin{array}{l}\text { I'm always provided services, help and } \\
\text { assistance to other urban agriculture } \\
\text { community after participating in urban } \\
\text { agriculture program. }\end{array}$ & 0.0 & 0.0 & 0.0 & 33.3 & 66.7 & 0.479 & 4.667 \\
\hline $\begin{array}{l}\text { After participating in urban agriculture } \\
\text { program, mutual trust and benefit exists } \\
\text { among us and other urban agriculture } \\
\text { community members. }\end{array}$ & 0.0 & 0.0 & 13.3 & 10.0 & 76.6 & 0.718 & 4.633 \\
\hline $\begin{array}{l}\text { Other urban agriculture community } \\
\text { members and I have organized a small } \\
\text { discussion and consultation on farming } \\
\text { activities matter. }\end{array}$ & 0.0 & 0.0 & 3.3 & 33.3 & 63.3 & 0.563 & 4.600 \\
\hline $\begin{array}{l}\text { After participating in the urban agriculture } \\
\text { program, members from the other } \\
\text { community are willing to assist us. }\end{array}$ & 0.0 & 0.0 & 13.3 & 23.3 & 63.3 & 0.731 & 4.500 \\
\hline \multicolumn{8}{|l|}{ Linkage } \\
\hline $\begin{array}{l}\text { We and other urban agriculture community } \\
\text { have organized a small discussion and } \\
\text { consultation on farming activities matter. }\end{array}$ & 0.0 & 0.0 & 3.3 & 26.7 & 70.0 & 0.547 & 4.667 \\
\hline $\begin{array}{l}\text { I've received help and advice from } \\
\text { agriculture officer. }\end{array}$ & 0.0 & 0.0 & 3.3 & 30.0 & 66.7 & 0.556 & 4.633 \\
\hline $\begin{array}{l}\text { We and other urban agriculture community } \\
\text { have organized a small discussion and } \\
\text { consultation on marketing matter. }\end{array}$ & 0.0 & 0.0 & 3.3 & 33.3 & 63.3 & 0.563 & 4.600 \\
\hline $\begin{array}{l}\text { I've received help and technical advice } \\
\text { from non-governmental organizations. }\end{array}$ & 0.0 & 0.0 & 3.3 & 16.7 & 26.7 & 0.877 & 4.300 \\
\hline $\begin{array}{l}\text { We've provided several services, help and } \\
\text { support to other urban agriculture } \\
\text { community. }\end{array}$ & 0.0 & 0.0 & 23.3 & 26.7 & 50.0 & 0.828 & 4.267 \\
\hline
\end{tabular}

Table 3 indicated a level of social capital on bonding, bridging and linkage among respondents on urban agriculture program. The mean score for social capital on bonding, bridging and linkage aspects recorded as $4.811,4.685$ and 4.493 respectively whilst for the overall one is 4.550. Thus, it reflected that the respondents studied have a high level of bonding, bridging and linkage regarding on urban agriculture program. Urban agriculture program help to create a sense of community since it has given people an opportunity to communicate with their neighbour throughout the activity. Gallaher et al., (2013) in her study found that respondents who are participated in sack gardening are able to interact more frequently with each other and willing to help one another which consequently tighten up the bonding among them. 
Table 3: Level Of Social Capital On Bonding, Bridging And Linkage

\begin{tabular}{|c|c|c|c|c|}
\hline $\begin{array}{l}\text { Level of social } \\
\text { capital }\end{array}$ & Frequency & $\begin{array}{l}\text { Percentage } \\
(\%)\end{array}$ & Mean & SD \\
\hline \multicolumn{5}{|l|}{ Bonding } \\
\hline Low (1.00-2.39) & 0 & 0.0 & \multirow{3}{*}{4.811} & \multirow{3}{*}{0.362} \\
\hline $\begin{array}{l}\text { Moderate }(2.40- \\
3.69)\end{array}$ & 0 & 0.0 & & \\
\hline High (3.70-5.00) & 30 & 100.0 & & \\
\hline \multicolumn{5}{|l|}{ Bridging } \\
\hline Low (1.00-2.39) & 0 & 0.0 & \multirow{3}{*}{4.685} & \multirow{3}{*}{0.457} \\
\hline $\begin{array}{l}\text { Moderate } \\
3.69)\end{array}$ & 1 & 3.3 & & \\
\hline High (3.70-5.00) & 29 & 96.7 & & \\
\hline \multicolumn{5}{|l|}{ Linkage } \\
\hline Low (1.00-2.39) & 0 & 0.0 & \multirow{3}{*}{4.493} & \multirow{3}{*}{0.553} \\
\hline $\begin{array}{l}\text { Moderate } \\
3.69)\end{array}$ & 3.3 & 3.3 & & \\
\hline High (3.70-5.00) & 96.7 & 96.7 & & \\
\hline \multicolumn{5}{|l|}{ Overall } \\
\hline Low (1.00-2.39) & 0 & 0 & \multirow{3}{*}{4.550} & \multirow{3}{*}{0.514} \\
\hline $\begin{array}{l}\text { Moderate }(2.40- \\
3.69)\end{array}$ & 2 & 6.7 & & \\
\hline High (3.70-5.00) & 28 & 93.3 & & \\
\hline
\end{tabular}

Regarding table 4 and table 5, the paper will focus on the main objective of the study, which is to analyse any differences that exists between selected socio-demographic and social capital towards urban agriculture program by using Independent t-test and ANOVA. Is there any difference between male and female respondents towards this program? Result displayed in table 4 emphasized that gender factors reflect a significant difference towards the urban agriculture program $(\mathrm{t}=-0.966, \mathrm{p}=0.001)$. As the study result mentioned earlier, majority of the participants are from male group. There is a probability that male group have a strong social capital compared to female. Results gained here is similar to (Stone \& Hughes, 2002) findings which indicate that there is a relationship between female and male on social capital, which he stressed out that women are more trusting and social capital than men, and people with partners trusted more than those living without partners. For further analysis, ANOVA analysis was employed in this study. Based on the result, the age aspects do influence towards social capital on urban agriculture $(\mathrm{F}=7.557, \mathrm{p}=0.001)$. The highest mean score are from age range 41-50 $(M=5.0)$ whilst the lowest mean score are from age 31-40 which is 4.0. This result indicated that people with different age have different social capital towards urban agriculture program. Consequently, this finding noted that age is the major contribution that will drive community to have a good social capital towards community activity. For the marital status aspects, the result is insignificant towards the social capital on urban agriculture program with the $F$ value 1.381 and $\mathrm{p}=0.269$. Hence, the marital status does not reflect any social capital among the respondent on the program. Does level of education will affect the social capital among respondents towards urban farming program? Let's us discover the result on that. Education attainment of the respondents does not influence their social capital among them towards the program $(\mathrm{F}=1.139, \mathrm{t}=0.295)$. This concludes that respondents from different level of education have a similar social capital concept thus it will contribute a positive impact to the organization. 
The findings of the current study contradict with Wilson, (2000); Lowndes \& Wilson, (2001) and Nieminen, et al., (2008) who studied the dimension of social capital and demographic factors and realized that education had a strong, positive relationship with all the dimension of social capital. For the factor of working sector, based on the result presented, insignificant result $(\mathrm{F}=2.261, \mathrm{t}=0.124)$ between working sector and social capital on urban agriculture program. Someone career does not affect the relationship among respondents in the community. A further analysis on the mean score of household size shows the highest mean score is 5.00 for the household members $>7$ followed by 1-3 members (4.70) and 4-6 members (4.43). Based on F $(3,30)=2.582, \mathrm{p}=0.094$, there is no significant difference between household size and social capital on urban agriculture program. This result agrees with the finding of Babaei (2012) which showed insignificant relationship between family background (household size and head of household) factors and social capital.

Table 4: Comparison Between Age Variable and Social Capital on Urban Agriculture Program Using Independent t-test

\begin{tabular}{|c|c|c|c|c|c|}
\hline Variable & N & Mean & SD & t & p \\
\hline Gender & & & & & \\
Male & 17 & 4.47 & 0.45 & - & 0.001 \\
Female & 13 & 4.65 & 0.59 & 0.966 & \\
\hline
\end{tabular}

Table 5: Comparison Between Selected Socio-Demographic Factors (Age, Marital Status, Level of Education, Working Sector and Household Size) and Social Capital on Urban Agriculture Program Using ANOVA

\begin{tabular}{|l|l|l|l|l|l|}
\hline Variables & N & Mean & SD & F & p \\
\hline Age & & & & & \\
$31-40$ & 1 & 4.00 & 0.00 & 7.557 & 0.001 \\
$41-50$ & 10 & 5.00 & 0.00 & & \\
$51-60$ & 9 & 4.20 & 0.54 & & \\
61 and above & & & & & \\
Marital status & 1 & 4.00 & 0.43 & & \\
Single & 27 & 4.54 & 0.52 & 1.381 & 0.269 \\
Married & 2 & 5.00 & 0.00 & & \\
Widow & & & & & \\
& & & & & \\
Level of education & 0 & 0.00 & 0 & 1.139 & 0.295 \\
Primary school & 24 & 4.50 & 0.55 & & \\
Secondary & 6 & 4.75 & 0.27 & & \\
school/vocational & & & & & \\
College/university & & & & & \\
& 3 & 4.00 & 0.00 & 2.261 & 0.124 \\
Working sector & 11 & 4.68 & 0.34 & & \\
Government & 16 & 4.56 & 0.60 & & \\
Private & & & & & \\
Others & & & & & \\
Household size & 5 & 4.70 & 0.45 & 2.582 & 0.094 \\
1-3 & 21 & 4.43 & 0.53 & & \\
\hline
\end{tabular}




\begin{tabular}{|l|l|l|l|l|l|}
\hline $\begin{array}{l}4-6 \\
>7\end{array}$ & 4 & 5.00 & 0.00 & & \\
\hline
\end{tabular}

\section{Conclusion}

Referring to this study, it illustrates that the impact on socio-demographic factors on social capital on community towards urban agriculture program. Regarding on this study, it revealed that gender factor plays a significant part in social capital towards urban agriculture program. Based on the result, majority of respondents are male respondents which shows that men are more interested and available to join in the program. This is a good indicator for organizations or authorities to realize that gender is one of most significant factor that influence in social capital of community. Meanwhile for the age aspects, the factors do influence the community to have a strong social capital. It is essential for us to plan appropriate strategies to ensure the sustainability of the program since this program have a potential to gain a momentum in Malaysia. Hence, social capitals of each member of community which consist of social network and norms have an impact on community productivity whereby social capital element will provide leverage, develop cooperation between them which benefit community members. Social capital in community is an essential prioritize to look into before the authorities planning to implement a program in a community as a community with a positive social capital would encourage them to be more empowered in a certain program.

\section{References}

Babaei, H., Ahmad, N., \& Gill, S. S. (2012). Bonding, bridging and linking social capital and empowerment among squatter settlements in Tehran, Iran. World Applied Sciences Journal, 17(1), 119-126.

Blake, K., Vincent, N., Wakefield, S., Murphy, J., Mann, K., \& Kutcher, M. (2005). A structured communication adolescent guide (SCAG): Assessment of reliability and validity. Medical Education, 39(5), 482-491.

Cai, Y., Selod, H., \& Steinbuks, J. (2015). Urbanization and property rights. The World Bank https://elibrary.worldbank.org/doi/abs/10.1596/1813-9450-7486

FAO, 1999. Food insecurity: When people must live with hunger and fear starvation. Retrieved from http://www.fao.org/NEWS/1999/img/SOFI99-e.PDF.

Field, J., (2003). Social capital: An analytical tool for exploring lifelong learning and community development. British Educational Research Journal, 29(3), 417-433.

Freeman, D. 1991. A City of Farmers: Informal Urban Agriculture in the Open Spaces of Nairobi, Kenya. McGill University Press, Toronto.

Gallaher, C. M., Kerr, J. M., Njenga, M., Karanja, N. K., \& WinklerPrins, A. M. (2013). Urban agriculture, social capital, and food security in the Kibera slums of Nairobi, Kenya. Agriculture and Human Values, 30(3), 389-404.

Gittell, R. and Vidal, A. 1998. Community organizing: Building social capital as a development strategy. Sage Publications, Inc.

Grant, E. (2001). Social capital and community strategies: neighbourhood development in Guatemala City. Development and Change, 32(5), 975-997.

Grootaert, C., Narayan, D., Jones, V. N., \& Woolcock, M. (2004). Measuring social capital: An integrated questionnaire. The World Bank.

Ibrahim, Muhammad Bello (2016) Role of participation in decision making and social capital on sustainability of watershed usage among peri-urban agricultural farmers of Kwadon, Gombe State, Nigeria. PhD thesis, Universiti Putra Malaysia.

Kilpatrick, S. (2002). Learning and building social capital in a community of family farm businesses. International Journal of Lifelong Education, 21(5), 446-461. 
Lall, S.V., Selod, H., \& Shalizi, Z. (2006). Rural-urban migration in developing countries: A survey of theoretical predictions and empirical findings. World Bank Policy Research Working Paper No. WPS3915.

Levitte, Y. M. (2003). Social Capital and Aboriginal Economic Development: Opportunities and Challenges Yael M. Levitte. University of Toronto.

Lowndes, V., \& Wilson, D. (2001). Social capital and local governance: exploring the institutional design variable. Political Studies, 49(4), 629-647.

Midgley, J., \& Livermore, M. (1998). Social capital and local economic development: Implications for community social work practice. Journal of Community Practice, 5(12), 29-40.

Muhlke, C. (2010). Growing together. The New York Times Magazine, 8.

Narayan, D., \& Pritchett, L. (2000). Social capital: Evidence and implications. Social capital: A multifaceted perspective, 269-295.

Nieminen, T., Martelin, T., Koskinen, S., Simpura, J., Alanen, E., Härkänen, T., \& Aromaa, A. (2008). Measurement and socio-demographic variation of social capital in a large population-based survey. Social Indicators Research, 85(3), 405-423.

Nieminen, T., Martelin, T., Koskinen, S., Aro, H., Alanen, E., \& Hyyppä, M. T. (2010). Social capital as a determinant of self-rated health and psychological well-being. International Journal of Public Health, 55(6), 531-542.

Poulsen, M. N., McNab, P. R., Clayton, M. L., \& Neff, R. A. (2015). A systematic review of urban agriculture and food security impacts in low-income countries. Food Policy, 55, 131-146.

Putnam, R. (2001). Social capital: Measurement and consequences. Canadian Journal of Policy Research, 2(1), 41-51.

Putnam, R. D. (2000). Bowling alone: America's declining social capital. In Culture and Politics (pp. 223-234). Palgrave Macmillan, New York.

Putnam, R. D. (2000). Bowling Alone: The Collapse and Revival of American Community: New York: Simon and Schuster, 2001. Policy Analysis

Putnam, R. D. (Ed.). (2004). Democracies in flux: The evolution of social capital in contemporary society. Oxford University Press, USA.

Ruel, M. T., Garrett, J. L., Morris, S. S., Maxwell, D. G., Oshaug, A., Engle, P. L., \& Haddad, L. J. (1998). Urban challenges to food and nutrition security: A review of food security, health, and caregiving in the cities.

Stone, W., \& Hughes, J. (2002). Understanding community strengths. Family Matters, (61), 62.

Wakefield, S. E., \& Poland, B. (2005). Family, friend or foe? Critical reflections on the relevance and role of social capital in health promotion and community development. Social Science \& Medicine, 60(12), 2819-2832.

Wilson, E. O. (2000). Sociobiology. Harvard University Press.

Woolcock, M. (2001). The place of social capital in understanding social and economic outcomes. Canadian Journal of Policy Research, 2(1), 11-17.

Woolcock, M., \& Narayan, D. (2000). Social capital: Implications for development theory, research, and policy. The World Bank Research Observer, 15(2), 225-249.

World Bank, World Development Report 2000/2001: Attacking Poverty. 2001, New York: Oxford University Press. 